China's Demography and its Implications

Il Houng Lee, Xu Qingjun, and Murtaza Syed 
IMF Working Paper

Asia and Pacific Department

\title{
China's Demography and its Implications
}

\section{Prepared by Il Houng Lee, Xu Qingjun, and Murtaza Syed ${ }^{1}$}

Authorized for distribution by Il Houng Lee

0 DFK2013

\section{This Working Paper should not be reported as representing the views of the IMF.} The views expressed in this Working Paper are those of the author(s) and do not necessarily represent those of the IMF or IMF policy. Working Papers describe research in progress by the author(s) and are published to elicit comments and to further debate.

\begin{abstract}
In coming decades, China will undergo a notable demographic transformation, with its old-age dependency ratio doubling to 24 percent by 2030 and rising even more precipitously thereafter. This paper uses the permanent income hypothesis to reassess national savings behavior, with greater prominence and more careful consideration given to the role played by changing demography. We use a forward-looking and dynamic approach that considers the entire population distribution. We find that this not only holds up well empirically but may also be superior to the static dependency ratios typically employed in the literature. Going further, we simulate global savings behavior based on our framework and find that China's demographics should have induced a negative current account in the 2000s and a positive one in the 2010s given the rising share of prime savers, only turning negative around 2045. The opposite is true for the United States and Western Europe. The observed divergence in current account outcomes from the simulated path appears to have been partly policy induced. Over the next couple of decades, individual countries' convergence toward the simulated savings pattern will be influenced by their past divergences and future policy choices. Other implications arising from China's demography, including the growth model, the pension system, the labor market, and the public finances are also briefly reviewed.
\end{abstract}

JEL Classification Numbers: E21, E27, F32, J11, J18

Keywords: China, Aging, Demographics, Savings, Current Account, Global Imbalances Author's E-Mail Addresses: ilee@imf.org; msyed@imf.org; xuqingjun@mofcom.gov.cn

\footnotetext{
${ }^{1}$ Messrs. Lee and Syed are, respectively, the Senior and Deputy Resident Representative in the IMF's China office. Mr. Xu is Director of the World Economy Division in the Policy Research Department of the Ministry of Commerce of China. We would like to thank the Ministry of Commerce and the People's Bank of China for hosting seminars, and staff from these institutions as well as academic experts for their valuable comments. This paper has also benefitted from comments by the IMF China team.
} 


\section{Contents}

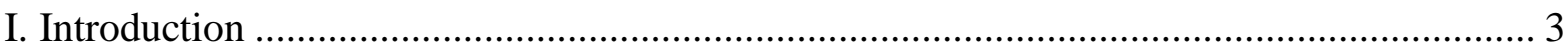

II. Literature Review .............................................................................................. 4

III. How Does Demography Affect Savings and the Current Account?.............................. 6

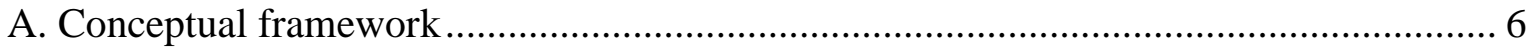

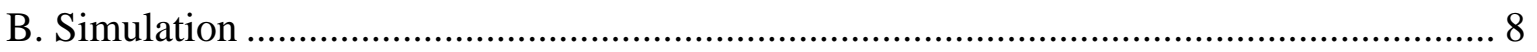

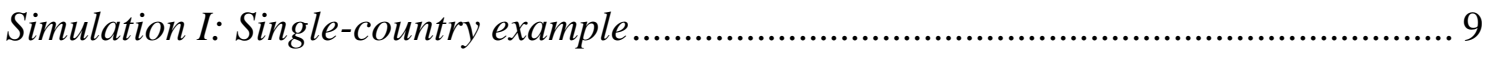

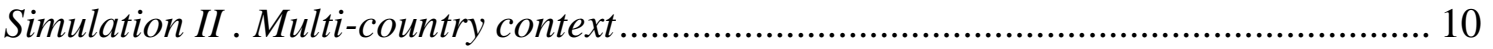

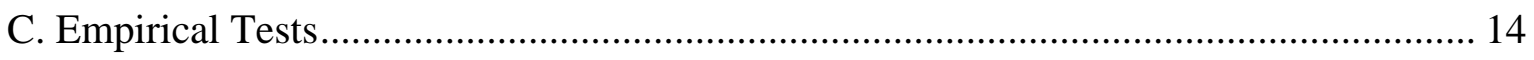

IV. Other Implications of China's Changing Demographics........................................... 18

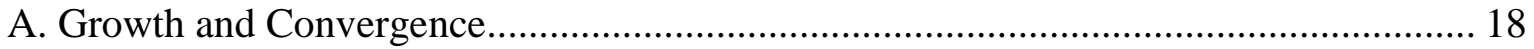

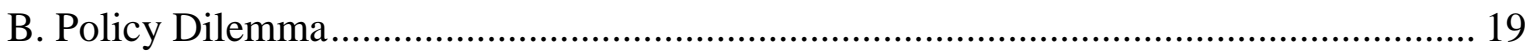

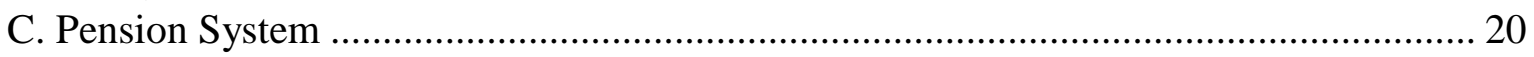

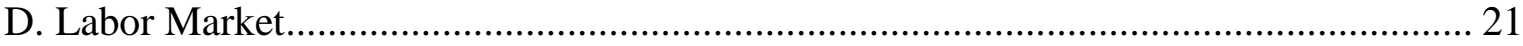

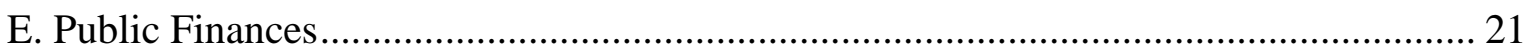

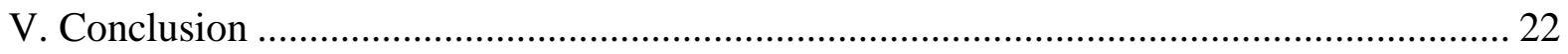

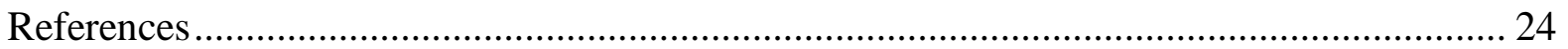




\section{INTRODUCTION}

China's population is expected to age rapidly in the next 50 years. By 2040, the large hump shown in Figure 1 as peaking at the age of 60 in 2030 will have shifted well into retirement age, with the working population largely replaced by the smaller population born after the one child policy. This change in demography will have a significant impact on various aspects of the economy, including on savings and consumption, the external balance,

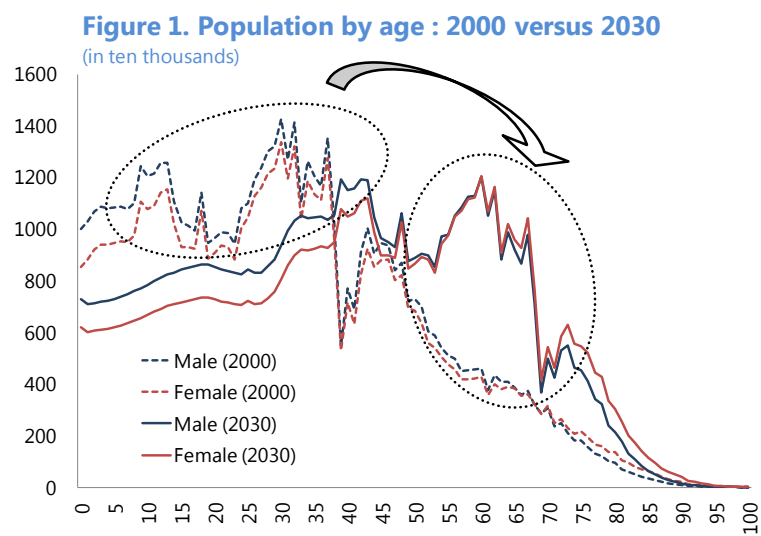
growth, the labor market, industrial structure, the pension system, the public finances, and have important implications for relevant policies in these areas. Mindful of these policy implications, the Chinese authorities have been cautious in expanding the pension system. They have also argued that on the basis of demographics, China's savings should be high now and only fall gradually over the next couple of decades.

This paper does not attempt to cover all these aspects, Given ongoing efforts to rebalance the Chinese economy toward domestic consumption, it reassesses national savings behavior with greater prominence and more careful consideration given to the role played by changing demography. In particular, we approach this subject using the basic permanent income hypothesis, under which households maximize consumption over their lifetime. Using panel data, we find that this approach not only holds up well empirically but may also be superior to the static dependency ratios typically employed in the literature.

Going further, we simulate the savings behavior of China and show that savings should have peaked in 2011 based on demographics alone. Accordingly, China's external balance should also have peaked around that period, and should now be gradually declining, turning negative in the long run as China ages. We then add the United States, Europe, and Japan to China to represent the whole world. Adjusting for multilateral consistency, we find that China's demographics should have induced a negative current account in the 2000s because it was still relatively young compared to the rest of the world and a positive one in the 2010s as the labor force saves in anticipation of population aging, while the opposite is true for the United States and Western Europe. Other implications arising from China's demography, including the growth model, the pension system, the labor market, and the public finances are briefly reviewed at the end of the paper.

These results indicate that China is currently in a position of relative strength as it saved even when it was able to afford spending more on the back of its younger population. As China integrated into the global economy during the 1990s and 2000s, the high degree of 
underemployment and large size of new entrants to the labor market since then have suppressed wage growth. This contributed to the decline in the wage share of GDP during this period, allowing a large part of corporate income to be saved and reinvested. The United States, on the other hand, will be swimming against powerful demographic currents in attempting to achieve fiscal consolidation and reverse its trade deficit during the next decade. During this period, demography will be pushing it toward lower savings and a current account deficit.

We posit that the observed divergence in current account outcomes from the simulated path may also have been the result of policy distortions. This includes expansionary macroeconomic policies that allowed the United States to consume more than would have been consistent with its demographic profile. Under this hypothesis, developments in across countries were closely intertwined, mainly through the trade channel, but also through the finance channel, as expansionary monetary policy in the United States was further fueled by reflow of capital from China and other emerging markets through reserve accumulation of the latter (Choi and Lee, 2010). On the Chinese side, an underdeveloped social safety net may also have contributed to the excessive build-up of savings.

Domestically, China's aging implies that savings will continue to remain strong over the medium term. The size of the working population will stay relatively stable for another decade, after which it will start to decline gradually. The expected increase in the number of retirees over the long term poses a challenge regarding how best to manage savings to ensure the real purchasing power per yuan saved now is not eroded over time. Savings can be allocated between domestic investment and investment abroad, returns on which will be determined by the efficiency of investment and the optimal portfolio management of foreign assets, respectively. The former issue is addressed in a separate paper (Lee et al. (2013b) forthcoming).

Over the next couple of decades, individual countries' convergence towards the simulated savings pattern will be influenced by their past divergences and future policy choices. The cumulative divergence of the actual from the simulated path, be it due to labor dividend in China or expansionary policies in the United States, will influence future household savings behavior. If the divergence was positive, i.e., actual savings exceeded the simulated path, then the future savings will tend to underperform the simulated path to compensate. This assumes, of course, that policy choices are such that they help the household sector to make optimal decisions in maximizing their consumption.

\section{LITERATURE REVIEW}

In recent years, there have been a number of studies on the relationship between 
demographics and savings behavior in China. ${ }^{2}$ Using a lifecycle model, Modigliani and Cao (2004), Horioka and Wan (2007), Horioka (2010), Song and Yang (2010), and Fan and Zhu (2012) find evidence of a significant relationship between saving rates and the age structure of the population.

Projecting forward, Kuijs (2006) expects China's savings to remain high until around 202025 , as the negative impact on saving from a rising old-age dependency ratio is offset by the impact of a continued decline in the young age dependency ratio. After 2025 or so, when the former continues to increase but the latter stabilizes, the net negative effect on saving behavior eventually becomes very substantial. Chamon and Prasad (2005) have a broadly similar conclusion, with demographic factors by themselves implying higher household saving over the next decade. They also suggest that these effects could switch and become less ambiguous after around 2025, as the old-age population continues to rise and the working-age population becomes more dominated by low-saving younger cohorts. Similarly, Horioka and Terada-Hagiwara (2012) project China's savings rate to continue increasing until 2030, as its population ages relatively more slowly than a number of other Asian economies, with its population share of retirees crossing 14 percent (the accepted definition of an "aged society") only toward the end of this period.

A few studies have also explored the potential impact of China's demographic changes on net savings, i.e. its current account balance. IMF (2008) uses a multi-country panel regression to estimate determinants of current account balances, with a focus on the impact from aging. The novel feature of the exercise is that the standard demographic variables are expressed relative to trading partners, reflecting the fact that countries

need to be at different stages of the demographic transition in order for it to have an impact on their external positions. With China expected to age relatively slowly compared to most of its trading partners, the paper predicts that the impact of demographics on China's current account impact will remain persistently positive over the long-term, as its share of prime savers rises relative to those of its trading partners. By contrast, the impact is significantly negative for both the United States and Japan over the next 20-30 years and becomes negative for Germany after around 2025.

Based on projected changes in the fraction of the population in the prime savers cohort (4059) around the world, Haldane (2010) and Bank of England (2011) find that medium-term pressures on global imbalances could triple over the next twenty years, with saving rates rising among surplus countries as their prime savers share rises (including in China) and falling in deficit countries as their prime savers share declines (including in the United States and other developed economies). For China, the saving rate would only start falling in the

\footnotetext{
${ }^{2}$ A number of recent studies have also found a significant impact of demographics on savings in an international context, including Chen et al. (2006), Fehr et al. (2007), and Krueger and Ludwig (2007).
} 
late 2020s and would continue to rise as a percent of total G-20 savings at least until then. Its current account could reach as high as 2 percent of global GDP over this period, only turning into a deficit after 2045. While acknowledging that such a focus on demographics alone obscures the impact on the current account of other changes like adjustments in real exchange rates, reduced investment as the marginal product of capital falls, and lower saving rates in emerging markets as the social safety net is further developed, the paper cautions that these would have to be very significant to counterbalance the medium-term upward pressures on global imbalances arising from powerful demographic forces. The results presented in our paper are quite close in substance to the findings in these three studies.

As is typical in the literature, the empirical work in the papers discussed above relies on reduced form regressions and static dependency ratios. By contrast, the approach in our paper is closest in spirit to Curtis et al. (2011) in terms of taking into account the entire age distribution and incorporating the future time-path of demographics and other variables. Their paper finds that incorporating changing demographics in this way can help explain much of the evolution in China's household saving rate between 1955 and 2009. In particular, China's current high savings is argued to have primarily been driven by reduced family size from the one-child policy and the relatively large share of the working-age population.

\section{How Does Demography AfFect SAVings AND the Current Account?}

\section{A. Conceptual framework}

Our framework rests on the "permanent income" hypothesis. As a result, household savings will be determined by both the demographic structure and the time horizon over which households maximize their consumption. In this simple framework, "household" represents both consumers and producers with no public sector. An extension to include the government can be made, but this will not have any meaningful implication on saving behavior of the economy if both households and the government are assumed to maximize consumption over the long run, and thus behave in the same way.

A person will maximize his/her consumption over their life span which can be divided into period 1 and 2 (Figure 2). During period 1, the individual generates income, part of which he/she saves so that they can live off the saving in period 2, i.e., after retirement. Thus, a person's maximization problem can be described as: Max e $=e_{1}+\left[e_{2} /(1+\rho)\right]$ w.r.t. saving, $s$, and subject to $\mathrm{y}=\mathrm{e}_{1}+\mathrm{s}$, and where $\mathrm{e}_{2}=\mathrm{f}(\mathrm{s})$ with $\mathrm{f}^{\prime}>0, \mathrm{f}^{\prime \prime}<0$, and $\mathrm{y}$ is predetermined by the capital stock/productivity and technology as captured in production function $\mathrm{f}$ in pre-period 1 . In addition, $\mathrm{e}$ is consumption, $\mathrm{y}$ income, and $\rho$ the discount factor for time preference. The optimal solution represented by the first-order condition is the usual $\mathrm{f}^{\prime}=(1+\rho)$, which can be graphically expressed as shown above (Figure 3).

This can be extended to a multi-period model where $e_{2}(s)$ becomes $y$ in the second generation's period 1 . The second generation would then have to be financed by the first 
generation's income in Period 1, but in Period 2, they would supplement the savings of the first generation with their own income. That income, however, will depend on productivity in that period, which in turn will be a function of the capital stock (s) and technology (exogenous).

\section{Figure 2}

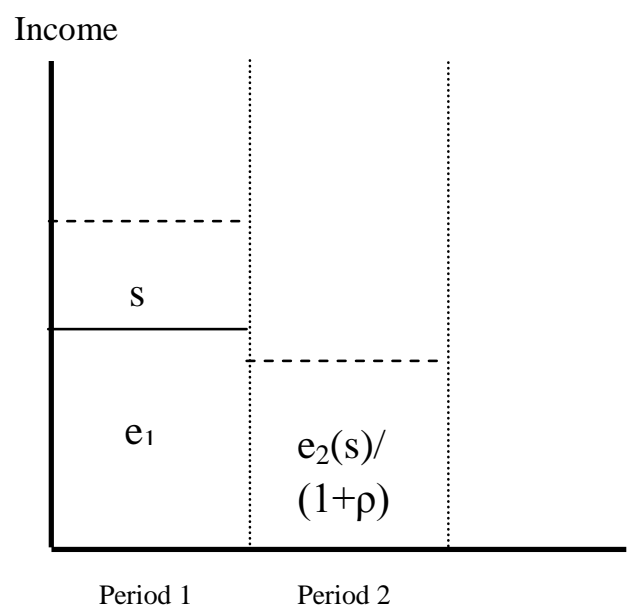

Figure 3

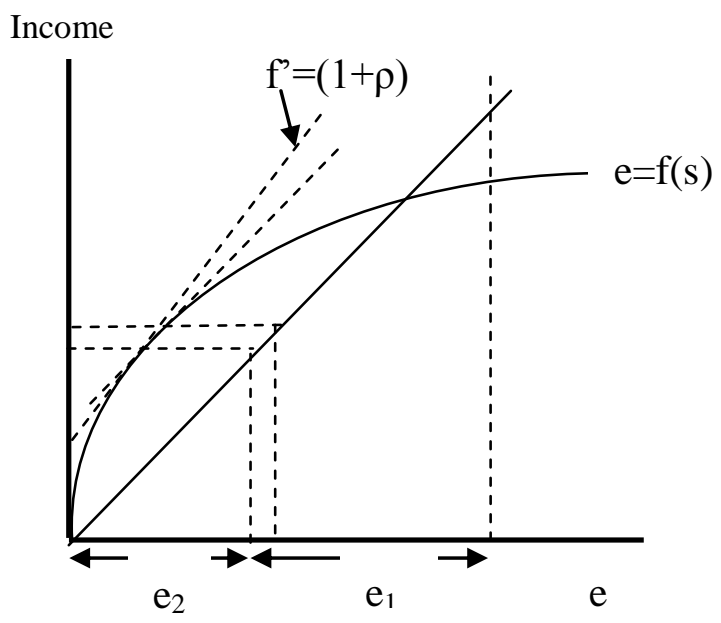

\section{Aggregation}

Suppose that all individuals are identical, or at least on average behave in a sufficiently similar manner. Then the aggregate of individuals would represent the economy. The analysis becomes somewhat more complicated if we have varying populations. Let us suppose that in Period 1 there are two generations, $\mathrm{G}_{1}$ and $\mathrm{G}_{2}$. Capital letter $\mathrm{E}_{\mathrm{ij}}$ represents aggregate spending in period $d_{i}$ by $G_{j}$ where $i, j=[1,2]$. In a multiple overlapping generation model, $\mathrm{E}_{11}$ should include $\mathrm{E}_{01}$, and $\mathrm{E}_{22}$ should include savings for the next period.

The optimization problem is then to maximize $E_{1}+Y_{2}$, where $E_{1=} E_{11}+E_{12}$ and $Y_{2}=E_{22}+E_{21}=E_{2}$. Both $\mathrm{E}_{21}$ and $\mathrm{E}_{22}$ are determined by $\mathrm{F}\left(\mathrm{S}, \mathrm{G}_{2}\right)$. Savings in period 1, on the other hand, is affected by $\mathrm{E}_{12}$ through $\mathrm{G}_{2}$ (Figure 4).

$\operatorname{Max} \mathrm{Z}=\mathrm{Y}_{1}-\mathrm{S}\left(\mathrm{G}_{2}\right)+\mathrm{Y}_{2}\left(\mathrm{G}_{2}\right) /(1+\rho)$; s.t. $\mathrm{Y}_{1}=\mathrm{S}+\mathrm{E}_{1}$ and $\mathrm{Y}_{2}=\mathrm{F}\left(\mathrm{G}_{2}, \mathrm{~S}\right)$

The first-order conditions are: (1) $\mathrm{dZ} / \mathrm{dS}=0$ and (2) $\mathrm{dZ}^{\mathrm{d}} \mathrm{dG}_{2}=0$

Thus, $\mathrm{dF} / \mathrm{ds}=(1+\rho)$ as was the case for the individual, and $\mathrm{dF} / \mathrm{dG}_{2}=(1+\rho) \mathrm{dS} / \mathrm{dG}_{2}$

An increase in G2 reduces S in Period 1, and in period 2, the net effect on $\mathrm{Y}_{2}$ will depend on the relative impact of lower savings (i.e., capital stock) and more labor (Figure 5. In other words, an expected increase in working population in the future (relative to the current size) will reduce current savings. This implies that under the permanent income hypothesis, an expected decline in working population in the future will increase current savings so that the 
difference between future and current income is minimized.

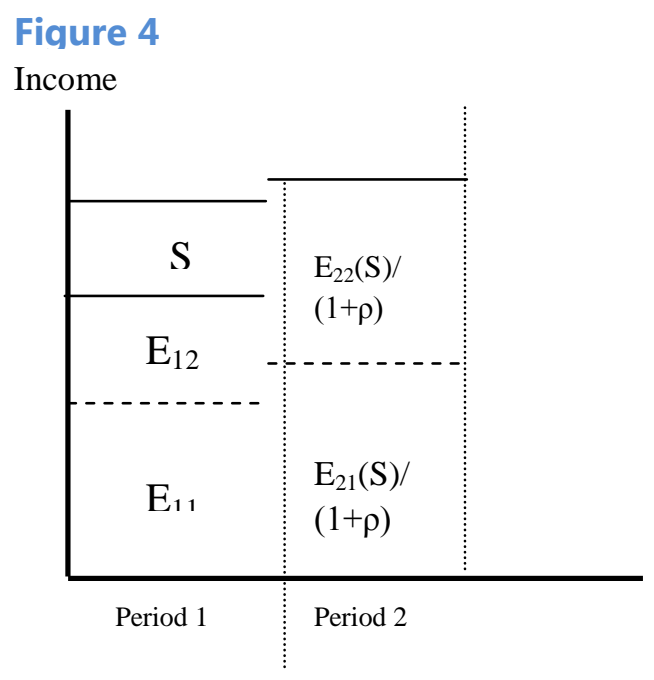

\section{Figure 5}

Saving; $Y$

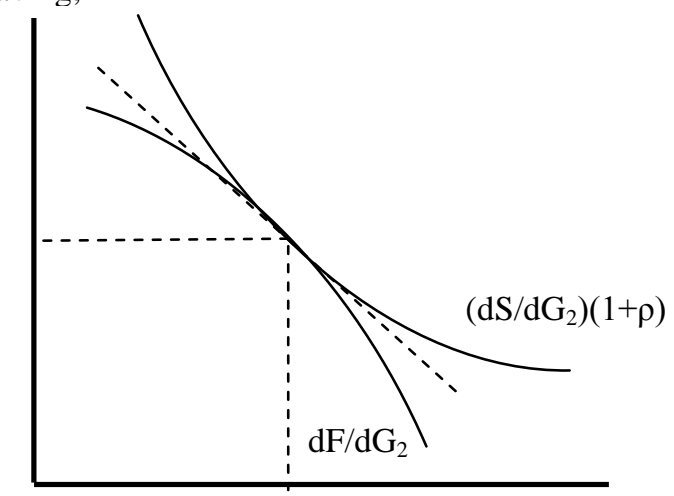

G

\section{The role of liquidity}

Liquidity affects asset prices. Liquidity affects the nominal value of savings since they are in the form of capital, whose prices are affected by liquidity.

$\mathrm{Y}_{1} \mathrm{P}=\mathrm{SP}_{\mathrm{S}}+\mathrm{EP}_{\mathrm{E}}$ or $\mathrm{Y}_{1}=\mathrm{S}\left(\mathrm{P}_{\mathrm{S}} / \mathrm{P}\right)+\mathrm{E}\left(\mathrm{P}_{\mathrm{E}} / \mathrm{P}\right)$, where $\mathrm{P}_{\mathrm{S}}=\mathrm{P}($ Liquidity $), \mathrm{P}^{\prime}>0$.

The first-order condition from the maximization problem from above is $S^{*}$ where $F\left(S^{*}\right)=(1+\rho)$ and $\mathrm{S}^{*}=\mathrm{S}\left(\mathrm{P}_{\mathrm{S}} / \mathrm{P}\right)$

Thus, if $S\left(P_{S} / P\right)>S^{*}$ because $P_{S}>P$, which is the case if $L$ is higher than $L^{*}$ where at $P_{S}\left(L^{*}\right)=P$, then $S<S^{*}$. In other words, if liquidity is excessive in period 1, then $S$ is smaller than optimal savings.

\section{B. Simulation}

To capture the dynamics of demography for simulation purposes, the population can be divided into 3 age groups as in Figure 6, those below working age (dissaving) $\mathrm{G}_{0}$, working age (income generating and saving) $\mathrm{G}_{1}$, and retired age (zero saving) $\mathrm{G}_{2}$.

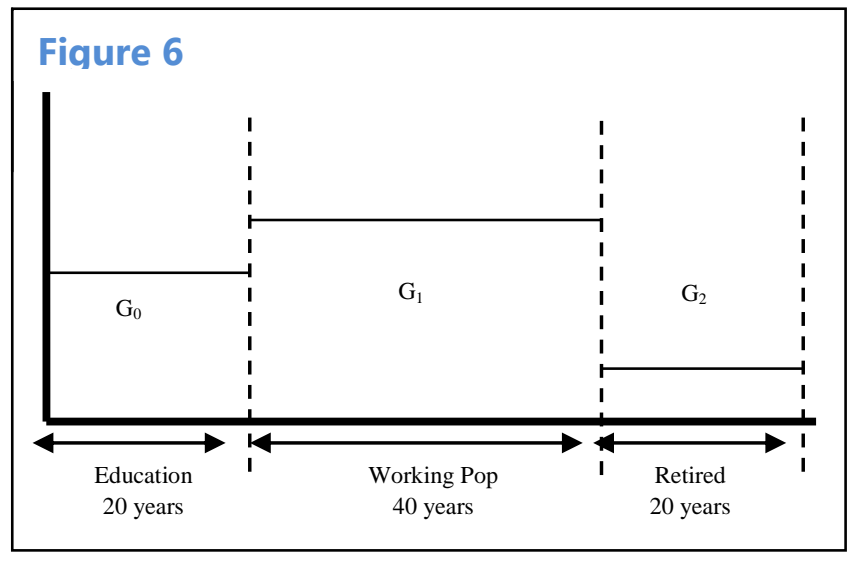




\section{Simulation I: Single-country example}

Out of a normalized total income of 1 in each period, we assign a value of 0.4 to $G_{1}$, and 0.3 each to $G_{0}$ and $G_{2}$ for consumption. Income is generated by $\mathrm{G}_{1}$. We scale the whole income curve such that total income generated over the maximization period equals total consumption (Figure 7). The difference between the constructed consumption path and income is savings.

We do not explicitly account for the fact that savings can be used either for raising the domestic capital stock or the foreign capital stock. In the case of the former, this will introduce another layer of sophistication in the simulation to the extent that an increase in the capital stock will raise GDP growth in subsequent periods, thus compensating for the savings through a flow of higher income. This will raise the income profile and also somewhat change the consumption curve and savings as a share of income. In the case of the latter, savings will not raise domestic income, but that of the foreign country. The higher stream of income abroad can be transferred

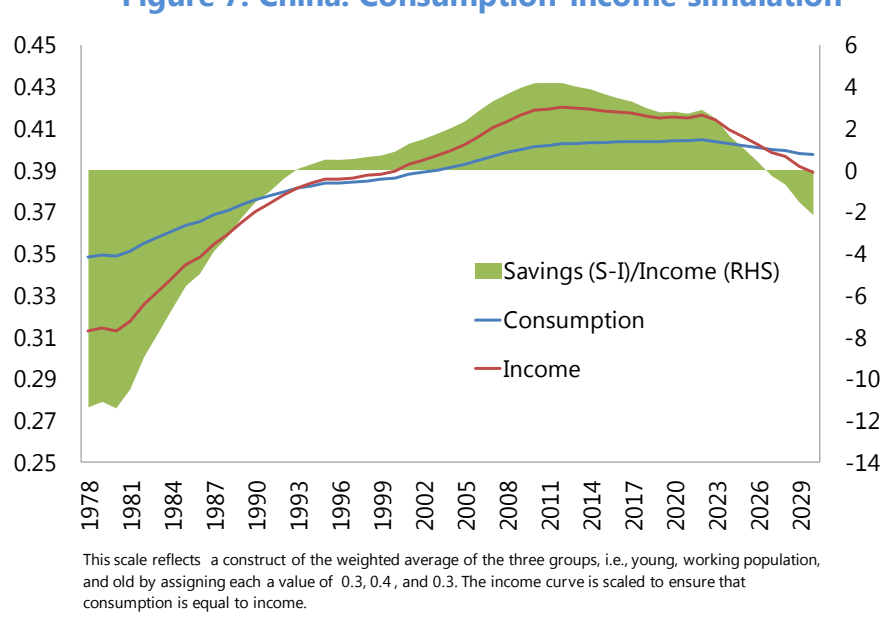

GDP Figure 8. Choice between higher GDP vs. placing savings abroad

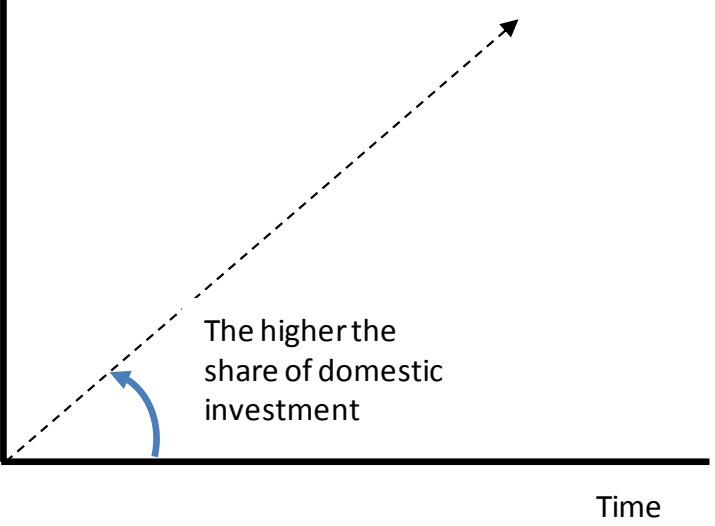
to the domestic economy for consumption. In our analysis, we only reflect this type of investment, and hence define the savings as net savings, or S-I, which is also called net external current account balance. The trade-off is between higher income (and consumption) versus lower income (and consumption) but windfall income later. So, underlying the S-I outcome is a complex relationship between income and investment where total income will need to be higher than consumption in the first place, a large part of which is subsequently used to generate a faster domestic GDP growth path (Figure 8) .

Household behavior can be described as a dynamic maximization problem; e.g.,

$\operatorname{Max} Z=\int_{0}^{T} Y(t, \delta I(t)) d t \quad$ s.t. $\int_{0}^{T} C(t) d t=\int_{0}^{T} Y(t) d t$

where $\mathrm{Y}$ is income, $\mathrm{C}$ is consumption, and $\delta$ is the discount factor. 
Actual net savings broadly follow the simulated path, although the former is more elevated and volatile reflecting the fact that actual investment tends to be much more erratic (Figure 9). The labor dividend and exogenous factors including strong global demand, coinciding with China's integration to world trade, are among the reasons why the actual outturn was higher than the simulated net savings during the 1990s and 2000s. Strong external demand was met by massive investment and greater use of labor. Excess supply of labor, however, ensured that unit labor costs remained low. Moreover, savings generated by the economy, especially those of the corporate sector which benefited from cheap capital and labor, provided a large part of investment without the need to resort to foreign borrowing.

\section{Simulation II . Multi-country context}

\section{The role of trading partner's demography}

Trading partner's demography will pull the S-I trajectory in different directions to ensure that the global total is zero. For example, in Figure 10, suppose country A's S-I is shown by the blue curve and that of country B as a straight line in red. Then the dotted lines are the respective $S$-I that will ensure market clearance. The sum of the two will need to add to zero.
Figure 9. China: Consumption-income simulation (in percent)

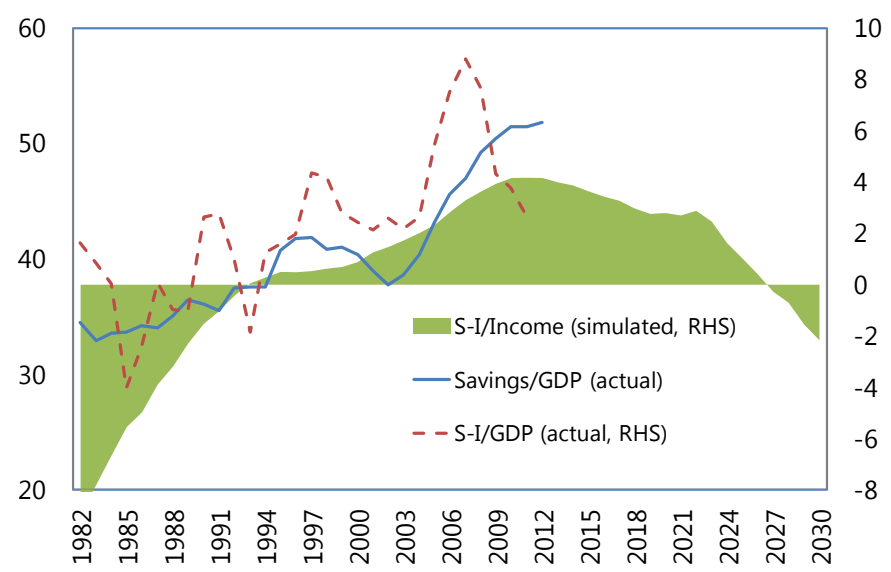


- $\quad$ Changes in the factors noted above could push S-I off the baseline path in the short run, but these deviations will have to be balanced out in later years as ultimately net savings will need to be equal to zero over the given time horizon and across countries at each point in time.

- If, for whatever reason S-I deviates from the baseline for a prolonged period, then there will have to be an abrupt adjustment in consumption. This of course assumes that the key fundamental affecting the baseline is demography.

- If the return on S-I (investment abroad) or return on domestic investment falls, then S-I tends to rise as people will want to ensure that their consumption level is maintained later. The allocation between domestic and foreign investment will adjust accordingly, with greater share going to investment that generate higher rate of return.

Following the illustration above, we generated S-I for the largest 4 groups/countries, namely Europe, Japan, US, and China (we proximate the world with these economies). The precise horizon over which the optimization takes place has some impact on the shape of the S-I curves, but does not fundamentally change the analysis. For example, lengthening the horizon from 1990-2030 to 1970-2050 shifts the point where most countries' curves intersect down from 2009 to 2005 (Figure 11).

Once adjusted for multilateral consistency where the sum of all countries' S-I has to be zero, we see that China's S-I peaks at around 2026 and then starts to decline (Figure 12). This delays the S-I peak by about 15 years because the aging in other countries sets in much earlier than in China (Figure 13), necessitating China to save for a longer period. This result is broadly robust to changes in growth rates except for the changes in the shape and slight shifts in the peaks (Annex I).

The period over which consumption is maximized has a notable impact on the scope
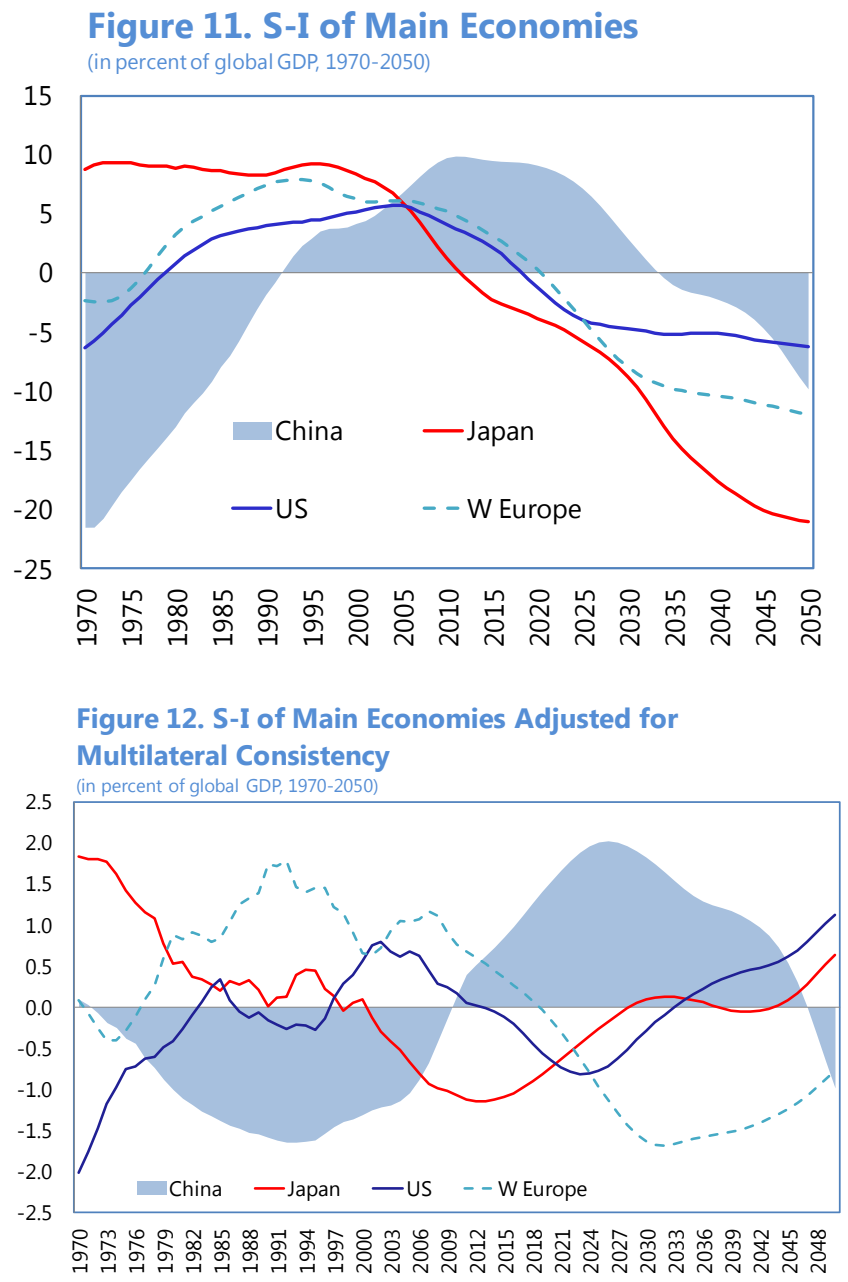
of net savings, especially when demography changes are large. For example, China's S-I 
Figure 13. Global Demographic Trends: Where Does China Stand?
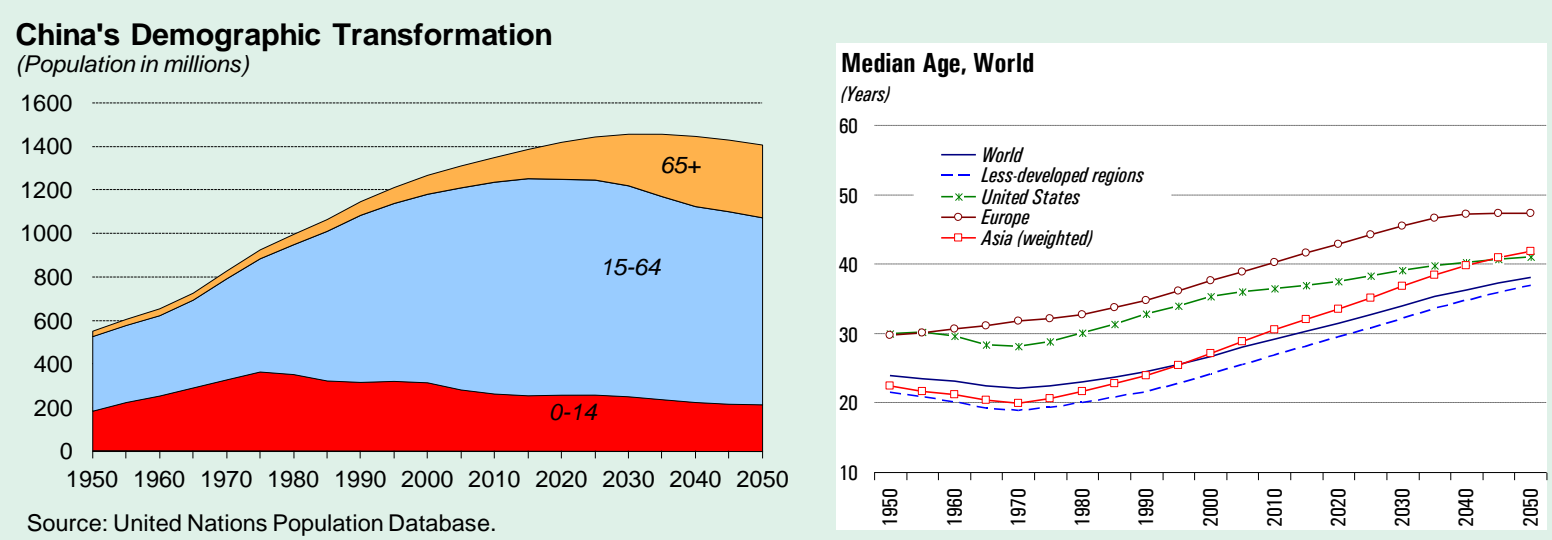

\section{Age Structure \\ (In percent of total population)}
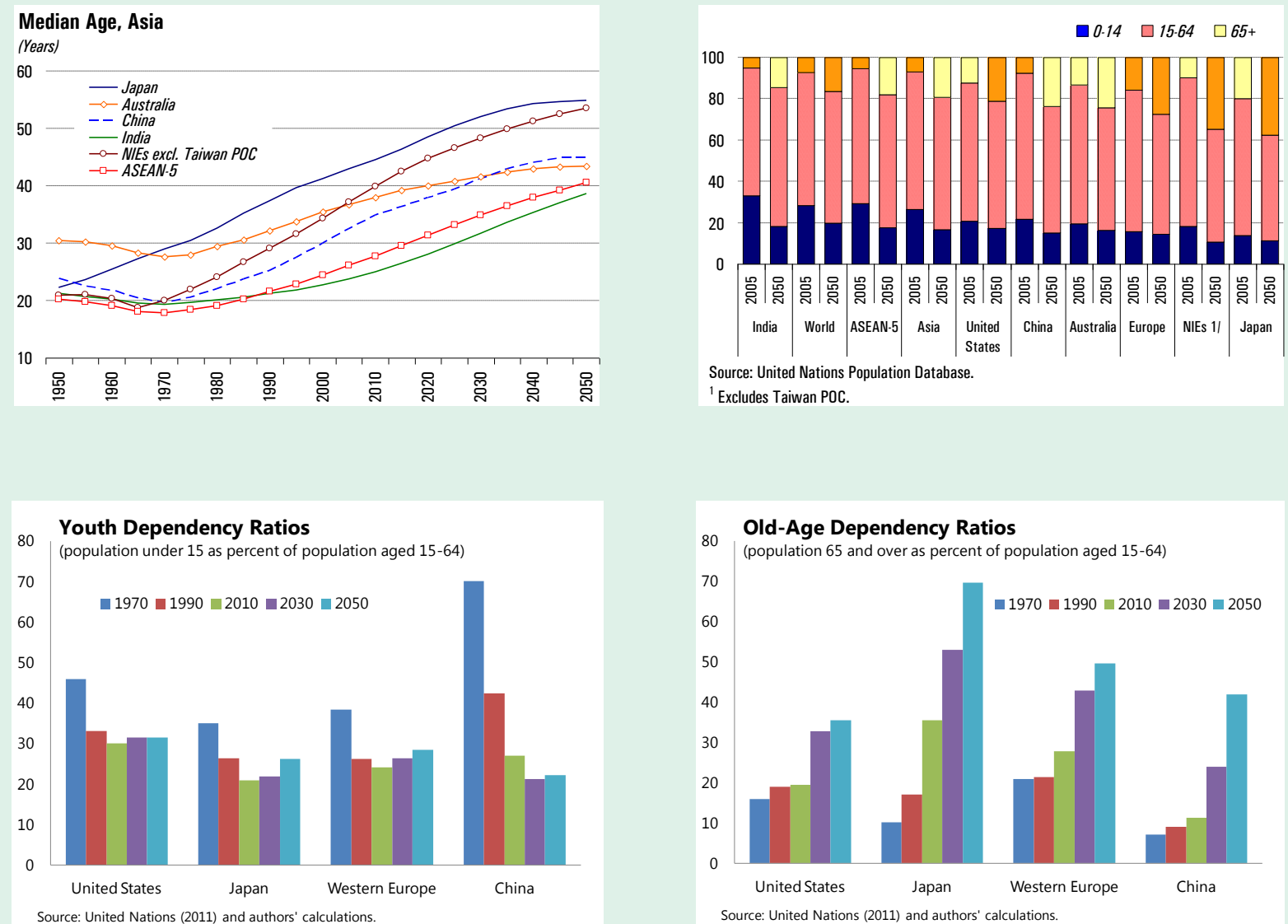
Source: United Nations Population Database.

profile shown in Figure 12 shows S-I peaking at close to 10 percent of GDP in 2011, while the simulation shown in Figure 8 peaks at 4 percent. The simulation in Figure 12 covers the period 1970-2050 where the demography profile changes are large at both ends, thus 
necessitating much larger savings during 2010-2030 period. The simulation in Figure 8 maximizes consumption only over the 1980-2030 period, which does not capture the large drops at both ends. Most likely, the shorter time horizon is closer to reality as demographic projections could change depending on changes in the birth rate, mortality rate, and participation rate.

In addition to fundamentals in classical growth models including the capital stock, labor, and productivity changes, other macroeconomic policy changes could also induce a change in the shape and timing of the curvatures. However, these deviations will have to be compensated later on because demographic forces are ultimately overpowering and cannot be resisted indefinitely. For example, an overly generous pension scheme will push up consumption beyond that consistent with the permanent income hypothesis. However, later, consumption has to be restricted in order to finance the over consumption in earlier years.

Our simulated path contrasts with actual developments to date because the global economy is of course not shaped by the permanent income hypothesis and demography alone. In particular, individual's optimization horizons may be shorter and differ across countries, and distortions, including from policy choices, may have misguided optimal consumption behavior. For example, the United States and Europe should have been running an S-I surplus during the 2000s according to our simulation. However, they have been running

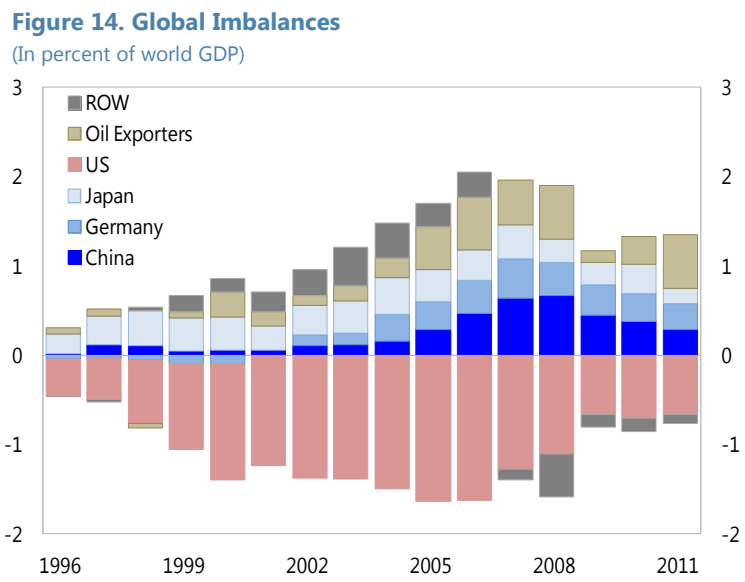
large deficits, leveraging their consumption beyond the optimal path with asset prices providing misleading signals and creating a wealth illusion (Figure 14). The opposite is true for China. It should have been running a deficit during most of the 2000s. Instead, it has run a very large surplus, thereby contributing to global imbalances, but cumulating valuable resources that it can use to finance the transformation of its economy.

Going forward, these cumulative divergences from the simulated path, i.e., the stock problem, will weigh heavily on cross-country savings behavior. For instance, based on demography, the US, Japan, and Western Europe will have to start running S-I deficits starting in the second half of the 2010s as their populations age relative to their trading partners. The stock problem, however, will induce households to save, and not spend, to make up for past mistakes. Fiscal consolidation efforts by these governments are part of this effort to save, which in a practical sense is described as rebuilding public balance sheets. If the stock problem is large, then the efforts by these governments alone may not suffice to address the stock problem, such that the economy may well face weak demand for the foreseeable future. In the case of China, the stock problem is reversed and could exert downward pressure on S-I 
beyond what demography itself might dictate. In particular, the younger generation, which has shown a much higher propensity for consumption, is expected to add to the downward pressure.

\section{Empirical Tests}

In this section, we test whether the underlying assumptions for the simulation above, i.e., the permanent income hypothesis and the role of demography, really matter.

\section{Permanent income hypothesis and demography}

As before, we define $G_{0}, G_{1}$, and $G_{2}$ to represent the young, working-age and retired population, respectively

In Figure 15, the solid lines represent demography at each indicated year. In the current year when decisions are made, attention is paid by savers $\left(G_{1}\right)$ to what the demographic structure will look like when they reach retirement age, relative to today. In particular, if the share of those in retirement $\left(G_{2}\right)$ to those of working age population today $\left(G_{1}\right)$ is expected to rise, this should push up savings. Conversely, if the share of those who are young $\left(\mathrm{G}_{0}\right)$ to

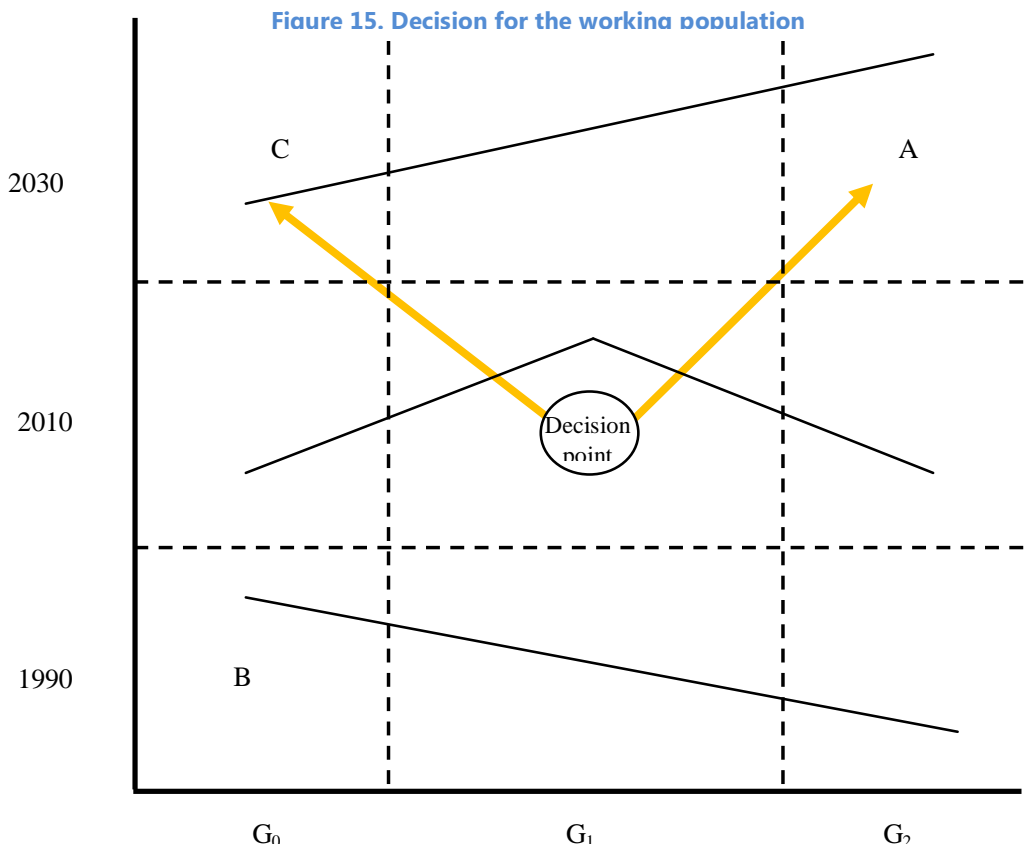
those of working age today is expected to rise, this should push down savings since the former will progressively enter the labor force and support those in retirement.

Practically, this would mean, for example, in 2010 comparing G1 in 2010 to G0 and G2 in 2030. In other words, the decision maker has to look at A and C relative to the working population today. Therefore, for the population in 2010, the savings decision will be influenced negatively by the ratio $G_{0} / G_{1}$ and positively by the ratio $G_{2} / G_{1}$, where $G_{0}$ and $G_{2}$ refer to the future.

In this way, our approach is more forward-looking than the typical method used to capture demographics in existing papers that are also based on an OLG framework. These papers usually focus on the share of prime savers, the young and the old in the current period, 
neglecting the importance of dynamics and expectations of future demography that are likely to have powerful effects on current behavior.

\section{Empirical application}

Building on existing literature and using the forward-looking demographic variables derived above, we estimated dynamic panel models for saving using GMM techniques and data for 57 advanced and emerging market economies over the period 1960-2011.

The models postulate that private savings, in any given economy $(i)$ and year $(t)$, are explained by the following factors:

$S i t=\alpha \operatorname{Si}(t-1)+\beta X i t+v i+\eta t+u i t$

$(i=1, \ldots, N ; t=2, \ldots, T)$

where Sit is the private saving-to-GDP ratio for economy $i$ in period $t$; Xit is a matrix comprising information on the explanatory variables for economy $i$ in period $t$; $v i$ is a country-specific effect; and $\eta t$ is a time-specific effect. The right-hand-side variables included in the saving regression are of two types:

- $\quad$ Past saving rate, $S i(t-1)$. This term captures the extent to which saving rates are persistent - that is, the extent current saving rates are correlated with past rates.

- Economic determinants of saving, Xit. The following determinants were considered, with the expected sign of the relationship between saving and each determinant in parentheses: public savings (- if Ricardian equivalence holds); per capita output growth $(+)$; real interest rate (+ or -, depending on whether the substitution or income effect dominates); growth in stock market capitalization as a proxy for liquidity (- if, as argued above, liquidity creates a wealth illusion); and alternative demographic variables, including the ones suggested by our conceptual framework, (G0/G1) (-) and $(\mathrm{G} 2 / \mathrm{G} 1)(+)$, as well as more conventional ones, namely the prime savers ratio $(+)$ and the youth dependency ratio (-).

The key results of this analysis are shown in Table 1:

- $\quad$ Fiscal consolidation is associated with lower private saving, as higher public saving is offset by adjustments in private saving behavior as predicted by Ricardian 
Table 1. Global Savings and Demography $1 / 2 / 3 /$

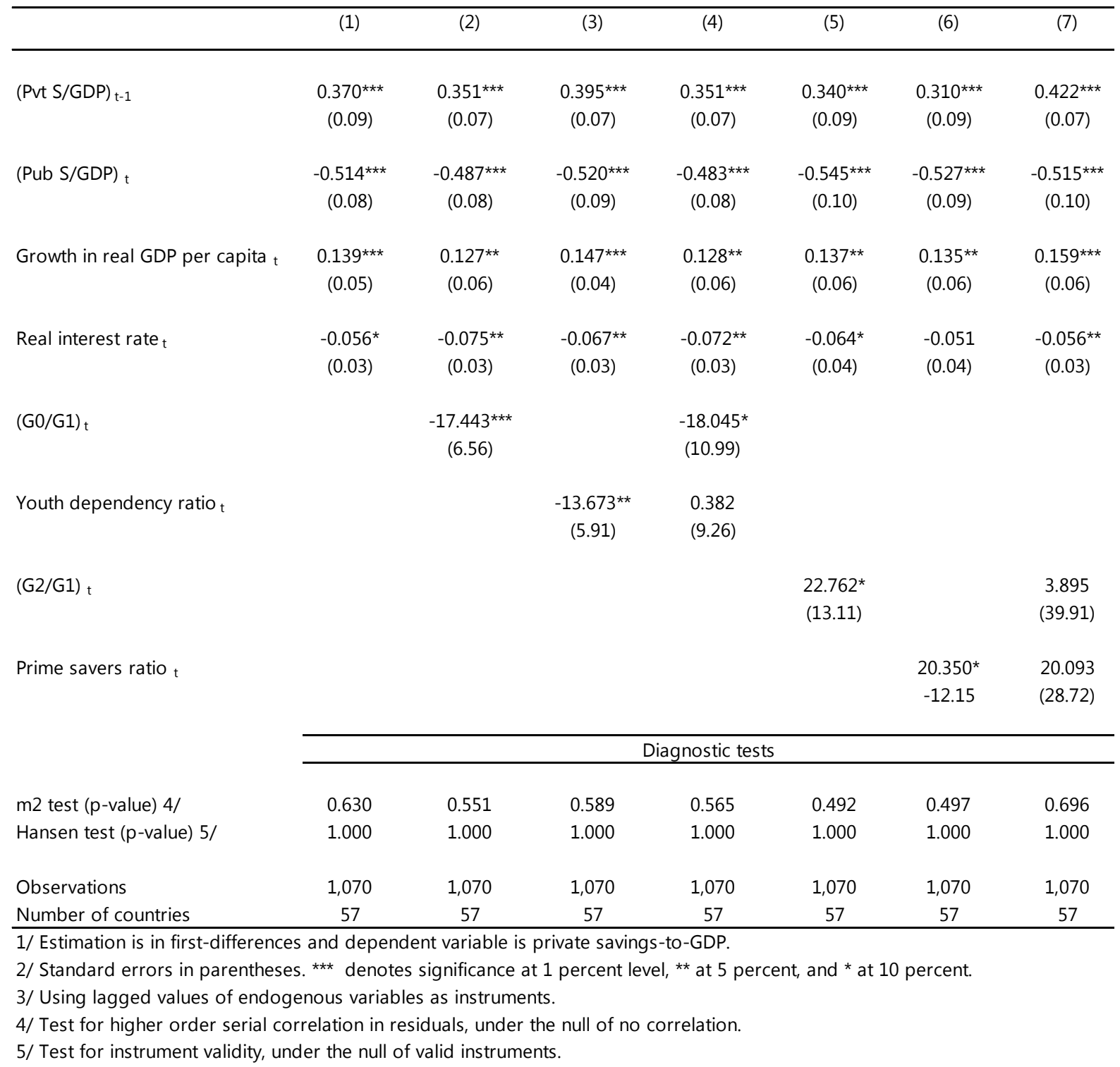

equivalence. In conducting sub-sample splits, we found this effect to predominantly reflect savings behavior in emerging markets. Based on our results, a 1 percent of GDP increase in public savings would lead over time to a 0.75 percent of GDP decrease in private savings. ${ }^{3}$

\footnotetext{
${ }^{3}$ This can be estimated as the ratio of the coefficient on the variable of interest over one minus the coefficient of lagged saving.
} 
- Higher output growth boosts saving. A sustained 1 percentage point increase in per capita output growth over time leads to an almost 0.2 percent of GDP increase in the private saving rate.

- An increase in the rate of return decreases savings. While saving and real interest rates are generally expected to be positively related - with the strength of this relationship likely to depend on the size of households' net asset position (Deaton (1992) — we uncovered a negative impact. This is consistent with the recent literature on target savings, under which the income effect of interest rate changes dominates savings behavior. We also found this effect to be predominantly a feature of the emerging markets in our sample.

- Both the forward-looking demographic variables developed in the earlier section are significant determinants of private savings and enter with the expected sign (Table1, columns 2 and 5). As the ratio of young people in the future is expected to rise, private savings decline. The opposite effect is detected if the ratio of the elderly is projected to rise in coming decades. The effects are also economically significant, with a 1 percentage point increase in G0/G1 (G2/G1) over time reducing (increasing) private savings by 0.25 percentage points of GDP.

- Moreover, there is also some evidence that these dynamic demographic variables are superior to the static ones typically employed in the literature. While the youth-dependency ratio (column 3) and prime saver share (column 6) are significant and enter our regressions with the expected sign, as found in other studies, the former is knocked out by our forward-looking G0/G1 variable (column 4), suggesting that the demographic information it captures is superior for explaining private savings.

Separately, we found that liquidity can decrease national savings and confound the effect of fundamentals, including demographics (Table 2). We found that increases in stock market capitalization as a percent of GDP are associated with a reduction in saving. In our estimations, we allowed this variable to be endogenous and instrumented it with private sector credit growth, consistent with the asset price channel of excess liquidity discussed in the sections above. This variable likely captures wealth effects associated with the sharp increase in asset prices driven by excess liquidity, which previous studies have found to have contributed to the reduction in household saving in a number of advanced economies since the 1990s, especially in the United States (Faulkner-MacDonagh and Mühleisen (2004)). Moreover, we found that excess liquidity/asset price growth can have powerful side-effects. In particular, it can temporarily knock out fundamentals, such as per capita output growth (column 1) and even our demographic variables (column 2). Even worse, it can totally confound their impact (column 3). 
Table 2. Exploring the Role of Liquidity $1 / 2 / 3 /$

\begin{tabular}{|c|c|c|c|}
\hline & (1) & (2) & (3) \\
\hline$(\text { Pvt S/GDP) })_{t-1}$ & $\begin{array}{c}0.282^{\star \star \star} \\
(0.08)\end{array}$ & $\begin{array}{c}0.241^{* \star *} \\
(0.09)\end{array}$ & $\begin{array}{c}0.251^{* * *} \\
(0.08)\end{array}$ \\
\hline$($ Pub S/GDP) $t$ & $\begin{array}{c}-0.591^{\star * \star} \\
(0.09)\end{array}$ & $\begin{array}{c}-0.621^{\star \star *} \\
(0.11)\end{array}$ & $\begin{array}{c}-0.640^{* \star *} \\
(0.12)\end{array}$ \\
\hline Growth in real GDP per capita ${ }_{t}$ & $\begin{array}{l}0.097 \\
(0.08)\end{array}$ & $\begin{array}{l}0.120^{*} \\
(0.07)\end{array}$ & $\begin{array}{l}0.121^{*} \\
(0.07)\end{array}$ \\
\hline Real interest rate $_{\mathrm{t}}$ & $\begin{array}{c}-0.104^{\star \star \star} \\
(0.03)\end{array}$ & $\begin{array}{c}-0.093^{* * *} \\
(0.03)\end{array}$ & $\begin{array}{c}-0.097^{\star \star \star} \\
(0.03)\end{array}$ \\
\hline Growth in stock market cap $\mathrm{t}$ & $\begin{array}{c}-0.015^{\star} \\
(0.01)\end{array}$ & $\begin{array}{l}-0.016^{\star} \\
(0.01)\end{array}$ & $\begin{array}{c}-0.017^{*} \\
(0.01)\end{array}$ \\
\hline$(\mathrm{G} 0 / \mathrm{G} 1)_{\mathrm{t}}$ & & $\begin{array}{l}-12.039 \\
(11.63)\end{array}$ & $\begin{array}{l}23.612 \\
(22.47)\end{array}$ \\
\hline \multirow[t]{2}{*}{$(\mathrm{G} 2 / \mathrm{G} 1)_{\mathrm{t}}$} & & & $\begin{array}{c}-13.673^{* *} \\
(5.91)\end{array}$ \\
\hline & \multicolumn{3}{|c|}{ Diagnostic tests } \\
\hline m2 test (p-value) $4 /$ & 0.630 & 0.551 & 0.589 \\
\hline Hansen test ( $p$-value) $5 /$ & 1.000 & 1.000 & 1.000 \\
\hline Observations & 758 & 758 & 758 \\
\hline Number of countries & 54 & 54 & 54 \\
\hline \multicolumn{4}{|c|}{$\begin{array}{l}\text { 2/ Standard errors in parentheses. }{ }^{* *}, * * \text { and }{ }^{*} \text { denote significance at } 1,5 \text {, and } 10 \text { percent level, respectively. } \\
3 \text { / Using lagged values of endogenous variables as instruments. Stockmarket cap instrumented by credit growth } \\
\text { 4/ Test for higher order serial correlation in residuals, under the null of no correlation. } \\
5 \text { / Test for instrument validity, under the null of valid instruments. }\end{array}$} \\
\hline
\end{tabular}

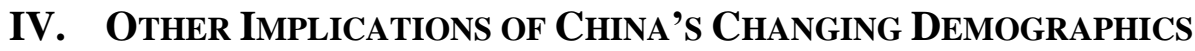

\section{A. Growth and Convergence}

A quick review of countries that managed to narrow the gap between their own and the US GDP per capita indicates that political stability and sound governance structures are prerequisite and necessary conditions for convergence. However, they are not sufficient and it seems that additional impetus is required to maintain sustained growth, namely rapid expansion of global trade, matched by large domestic investments. This is what China has 
been doing also. Strong external demand that followed the WTO accession was matched by a rapid supply response, made possible by massive investment and abundant supply of labor. Expected changes in China's demography will limit labor supply and thereby start raising unit labor costs. With population aging, investment will also likely fall as the returns to capital fall relative to scarcer labor and declining savings make capital more expensive.

Thus, demographic changes will add to the challenge of defining a new growth model as trade expansion and investment, the traditional engines of growth, will likely no longer be available to the same extent. In that sense, it seems international experience is only of relatively limited use in terms of defining the main engines that can help China sustain its growth. Instead, it appears that China will have to rely on home-grown solutions in terms of the precise engines that will help it achieve convergence with advanced economies.

Of course, the shrinking labor force may be partly offset if changes are introduced in government policies such as the one-child-policy or if there is an increase in immigration or participation rates, although these would take time to take effect. Moreover, total factor productivity gains from innovation, education, and labor mobility (partly through urbanization) could also raise per capita income and thereby affect savings.

\section{B. Policy Dilemma}

As discussed ealier, the divergence of the actual S-I path from that implied by demography may have been caused by various factors such as changes in economic fundamentals (e.g. change in preferences) and policy distortions. A similar situation may arise during the periods when the multilaterally adjusted S-I path diverges from its non-adjusted path. For example, as shown in Figure 16, S-I is lower under the adjusted path during the period between now and 2024. This means that China will need to have higher savings to maximize permanent consumption

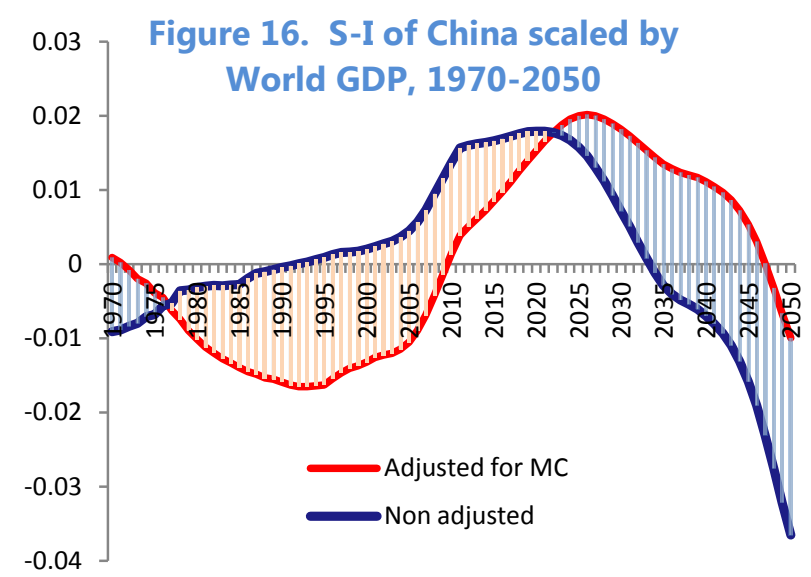
than would be dictated once adjusted for other countries' circumstances. There is no a priori reason why the actual outcome should follow the adjusted path unless induced by some policies. For the next decade or beyond, however, such a conflict may not arise as countries are in the process of addressing the stock problem of the past divergence of the actual from the simulated norm. One likely scenario is that China's savings may fall even below the adjusted path as it tries to rebalance from excessive savings in the past. Moreover, if investment efficiency is improved such that it facilitates more sustained consumption, this will also help rebalancing, together with current government efforts to strengthen social services in order to reduce precautionary savings. 


\section{Pension System}

While only the urban pension system is examined here, the implications from the illustration below will also apply to other part of China's multi-layered pension system. There are currently 285 million participants in the urban employees' basic pension insurance system, of which 215 million are contributors and 70 million recipients or retirees. The total size of the pension fund as of end 2011 stood at RMB 2 trillion. The benefit per retiree in 2011 at RMB 18,700 is about three times the contribution per employee. However, with the

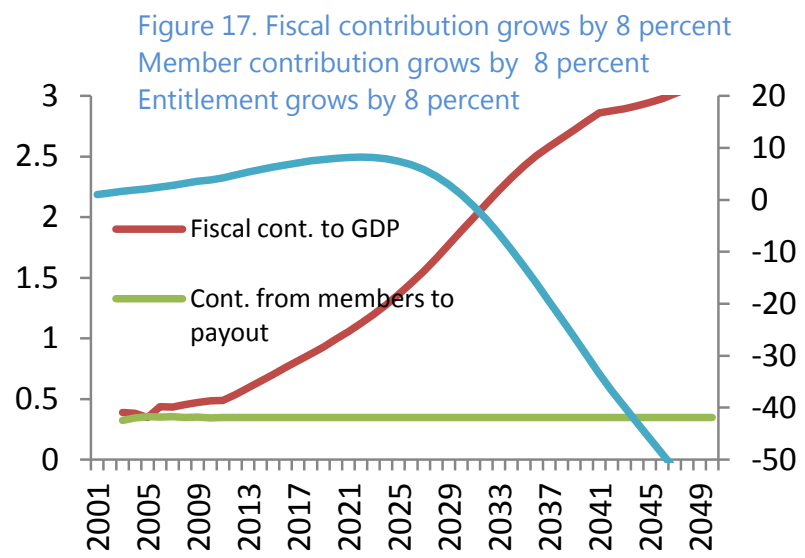
size of contributors about 3 times the retirees and fiscal contributions making up around a fifth of total payment, the pension fund has been growing steadily from about 1 percent of GDP in 2001 to 4.2 percent of GDP in 2011. The rate of return, however, has been relatively weak at 3.5 percent per year (average during the last 10 years) which is broadly the deposit rate.

Current coverage rate is relatively low with 40 percent of retiree receiving pension and only 26 percent of employees contributing to the pension system. Assuming that 70 percent of all retiree and employees will become participants of the pension system by 2030 and 2040, respectively, and a baseline scenario where nominal GDP growth average 8 percent over the next 40 years, the pension fund could be depleted if both contribution and entitlement grow by the same amount (Figure 17).

Other scenarios, which suggest the need for continued hikes in fiscal and member contributions in the absence of entitlement reductions, are (Figures 18 and 19):
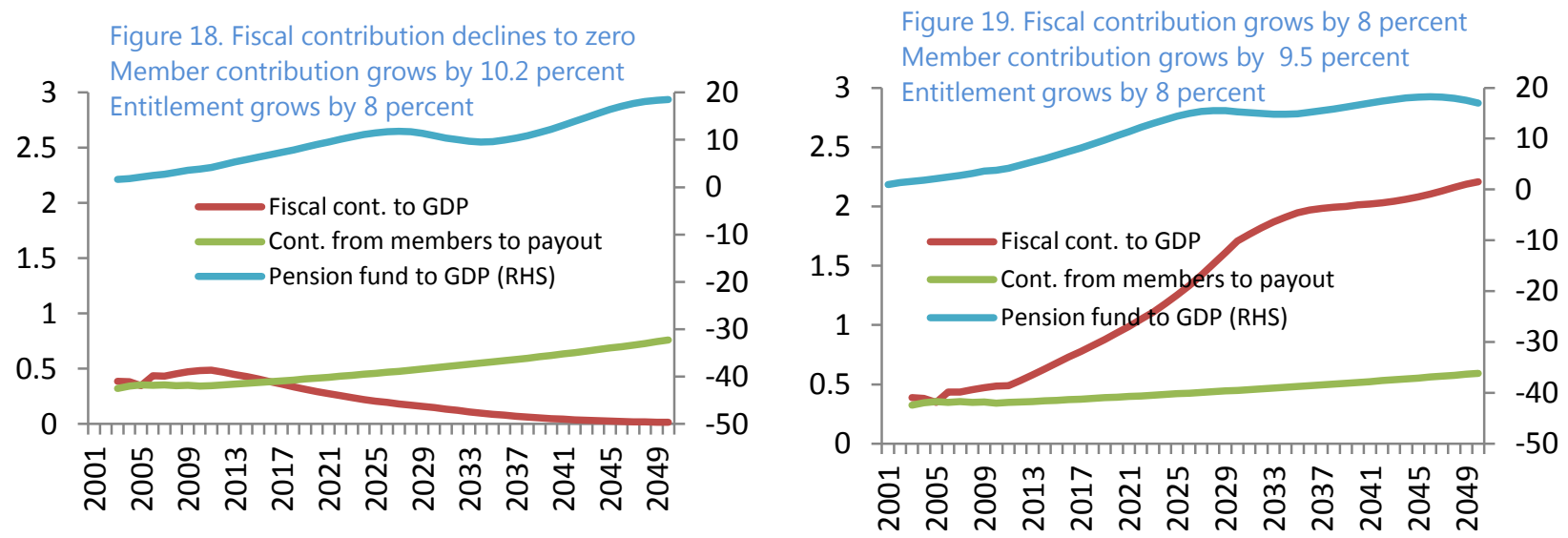


\section{Labor Market}

Demography indicates that China's problem over the next couple of decades will not be so much as a shrinking working population, but rather the end of the labor dividend that it enjoyed from the continued influx of labor over the past several decades (Figure 20). In the period ahead, China will have a labor market that more closely resembles those in

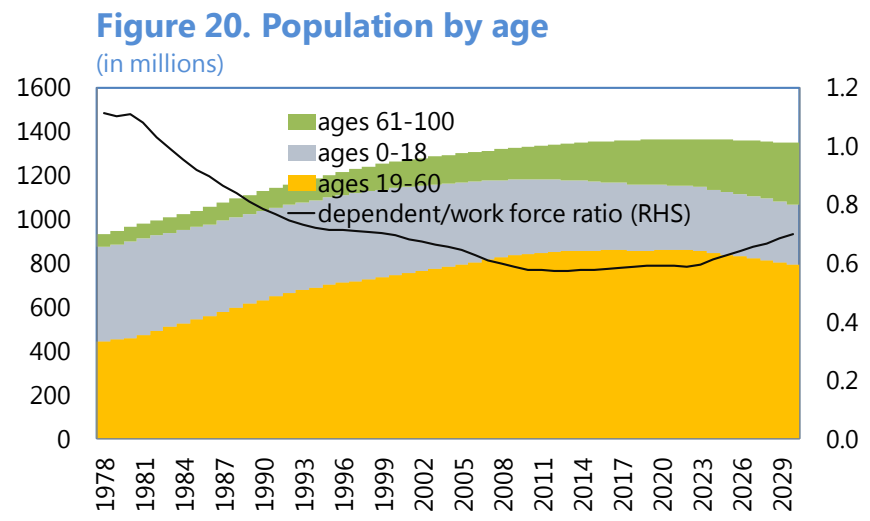
other countries. This will include rising unit labor costs, together with frictional and structural unemployment, particularly arising due to skill mismatches between growing college graduates and corporations that require more specialized skills.

To some extent, the expected reduction of new labor entrants lifts the pressure off the government that was previously hard pressed to ensure sufficient jobs were created to absorb the increasing working population. This is one of the reasons why China can afford a lower economic growth rate. It faces a different challenge, similar to those faced by other governments, namely how best to reduce the skill mismatch. Another challenge will be the need to cater for the dependent population, which will start to increase in earnest after 2024. This will require more savings going forward, the scope of which will partly depend on whether it can ensure the value of the past saving can be retained.

\section{E. Public Finances}

In addition to the pressures for higher government spending on pensions (as discussed above), health care and other welfare programs for the elderly, an aging population often translates into lower tax buoyancy due to a falling share of the labor force. Assuming no change in the retirement age, China's ratio of workers to retirees will drop from around 5:1 today to 2:1 by 2030. Therefore, assuming no change in tax structure, the tax burden on each worker will have to increase by around two and a half times for the government to maintain the current level of tax income.

While tax revenues have grown much faster than GDP over the last decade, this trend cannot be expected to necessarily continue as the proportion of working-age citizens shrinks. The most likely adverse impacts will be on personal income taxes. However, indirect taxes may also come under pressure since the elderly tend to spend less than younger people on goods and more on services, which are less often taxed. For instance, international experience 
cautions that the drop in tax receipts associated with aging is especially pronounced for income and payroll taxes, but also affects sales and property taxes.

To meet enhanced funding requirements for old-age expenditures, governments have typically had to modernize their tax systems. This involves efforts to keep existing tax bases from being eroded, as well as extending them into new areas, including reducing tax preferences, increasing dividends from state-owned enterprises, enhancing natural resource and energy taxation, increasing taxes on services, and diversifying and making revenue sources more broad-based (such as reducing reliance on taxes that the elderly are less able to pay out of fixed incomes).

\section{Conclusion}

Despite the divergence of actual net savings from the predicted path based on demography, empirical tests lend support to demography being an important determinant of savings. What are the potential policy implications of our findings?

First, demography dictates that China will experience a continued external current account surplus for a prolonged period as its population will still age relatively slowly than most of its main competitors over this period. With China's aging setting in much later, its population would likely want to save more. The stock of saving to date, however, will pull in the other direction. The announced policies to promote consumption and income inequality are to some extent geared toward achieving this intertemporal rebalancing. Strengthened social services and proper compensation of factors of production (labor and capital) will raise consumption as savings will likely fall as income share shifts from the rich to the poor and from corporates to households. The rationale is that in the absence of income inequality and full compensation of factors of input (which underlies the simulation results), China would have spent more in the past decade and less in the coming decade. Going forward, therefore, current policies will need to be geared towards correcting the past distortions that led to higher than demography-consistent savings.

Second, there could be some tension among countries as each strives to attain the savings that would optimize consumption over its lifetime cycle. In China, for example, its multilaterally adjusted next savings should be lower in the next decade and higher in the following two decades thereafter because it ages relatively slowly compared to other countries. However, because China over-saved in previous years, the inter-temporal rebalancing needed to unwind this should help the global outcome to align more closely with the multilaterally consistent SI path. Similarly, the next two decades thereafter, higher savings could be attainable by advanced countries if they deleverage and consolidate their fiscal position sufficiently to build up savings to make up for their previous lack of thrift. To avoid adding another distortion, it will be important to ensure that China's stock of savings generates adequate 
returns. If returns are low, this will, other things being equal, add additional pressure for savings.

Third, China's changing demographics make it essential to find a new growth model, since it can no longer rely on a large labor dividend and savings. A tightening labor market will start shifting income away from corporates to households. Even without the corrective policies discussed above, this shift will reduce corporate sector saving and investment, and raise household income and consumption. With corrective policies, the marginal propensity of consumption will also be larger. Thus, if investment is to be curtailed going forward as financing conditions tighten and especially amid growing concerns about excess capacity and continued overinvestment, then the only way to maintain robust growth is to start reaping dividends from efficiency gains and innovation. In terms of the labor market, China will need to make up for tightening conditions with better training for labor to reduce skill mismatches that will otherwise become an increasing constraint under a new growth paradigm.

Fourth, China's impending demographic changes suggest the need for caution in expanding the pension system. Continuation of the current status quo could run down pension funds in the next two decades as the pension scheme is expanded at a time when the number of retirees also starts to increase. While an expansion of the pension system is called for to ensure it covers a wider population, it will need to be carefully calibrated with inflows as an overly generous payouts could threaten the viability of the pension system in the future.

Fifth, in addition to increased old-age related spending obligations, China's tax revenues could come under pressure as the share of the working population shrinks in coming decades. This could put pressure on China's traditionally prudent public finances, necessitating countervailing changes in tax policy and administration that prevent the erosion of the tax base and extend it in new areas, including resources, energy and services sectors. 


\section{REFERENCES}

Bank of England, 2011, "The Future of International Capital Flows", Financial Stability Paper No. 12 - December 2011 (William Speller, Gregory Thwaites and Michelle Wright).

Chamon, Marcos and Eswar Prasad, 2005, "Determinants of Household Saving in China", International Monetary Fund, mimeo.

Chen, Kaiji, Ayse • Imrohoroglu, and Selahattin • Imrohoroglu, 2007, “The Japanese Saving Rate Between 1960 and 2000: Productivity, Policy Changes, and Demographics", Economic Theory, 32, pp. 87-104.

Fan Xuchun and Zhu Baohua, 2012, “China' s Life Expectancy Growth, Age Structure Change and National Saving Rate”, Population Research, 36(4).

Curtis, C., S. Lugauer, N. Mark, 2011, "Demographic Patterns and Household Saving in China", NBER Working Paper No. 16828.

Deaton, Angus, 1992, Understanding Consumption, Clarendon Lectures on Economics (Oxford: Oxford University Press).

Faulkner-MacDonagh, Chris, and Martin Mühleisen, 2004, “Are U.S. Households Living Beyond Their Means?” Finance and Development, Vol. 41, No. 1, pp. 36-9.

Fehr, Hans, Sabine Jokisch, and Laurence J. Kotliko, 2007, "Will China Eat Our Lunch or Take Us to Dinner? Simulating the Transition Paths of the United States, the European Union, Japan, and China", Fiscal Policy and Management in East Asia, NBER-EASE, Volume 16, University of Chicago Press, pp. 133-193.

Haldane, A., 2010, "Global imbalances in retrospect and prospect", available at www.bankofengland.co.uk/publications/speeches/2010/speech468.pdf .

Hoiroka, Charles Yuji and Junmin Wan, 2006, "The Determinants of Household Saving in China: A Dynamic Panel Analysis of Provincial Data", Journal of Money, Credit, and Banking, 39(8), pp. 2077-96.

Horioka, Charles Yuji, 2010, “Aging and Saving in Asia”, Pacific Economic Review, 15, pp. 46-55. 
Horioka, Charles Yuji, and Terada-Hagiwara, Akiko, 2011, "The Determinants and Longterm Projections of Saving Rates in Developing Asia", Japan and the World Economy 24(2), pp. 128-137.

International Monetary Fund, 2005, "Global Imbalances: A Saving and Investment Perspective”, World Economic Outlook (September: Washington DC).

International Monetary Fund, 2008, “The Graying of Asia: Demographics, Capital Flows,and Financial Markets", Asia and Pacific Regional Economic Outlook (November: Washington DC).

Krueger, Dirk and Alexander Ludwig, 2007, “On the Consequence of Demographic Change for Rates of Returns to Capital, and the Distribution of Wealth and Welfare", Journal of Monetary Economics, 54(1), pp. 49-87.

Kuijs, L., 2006, “How will China's saving-investment balance evolve?”, World Bank Policy Research Working Paper, No 3958, July.

Ma, Guonan and Wang Yi, 2010, "China's High Saving Rate: Myth and Reality”, BIS Working Paper, Number 312.

Modigliani, Franco and Shi Larry Cao, 2004, "The Chinese Saving Puzzle and the Life-Cycle Hypothesis", Journal of Economic Literature, 42, pp. 145-170.

Song, Zheng Michael and Dennis Tao Yang, 2010, "Life Cycle Earnings and Saving in a Fast-Growing Economy”, mimeo, Chinese University of Hong Kong.

United Nations, 2011, "World Population Prospects: The 2010 Revision" (CD-ROM Edition)_Extended Dataset in Excel and ASCII formats. New York: Population Division, Department of Economic and Social Affairs, United Nations.

Woon Gyu Choi and Il Houng Lee, 2010, "Monetary Transmission of Global Imbalances in Asian Countries" IMF Working Paper WP/10/214 (International Monetary Fund: Washington DC). 


\section{Annex I. Simulation Results}

Baseline: GDP growth over 2012-2050 in USD terms (China: 5 percent; others: 2 percent)

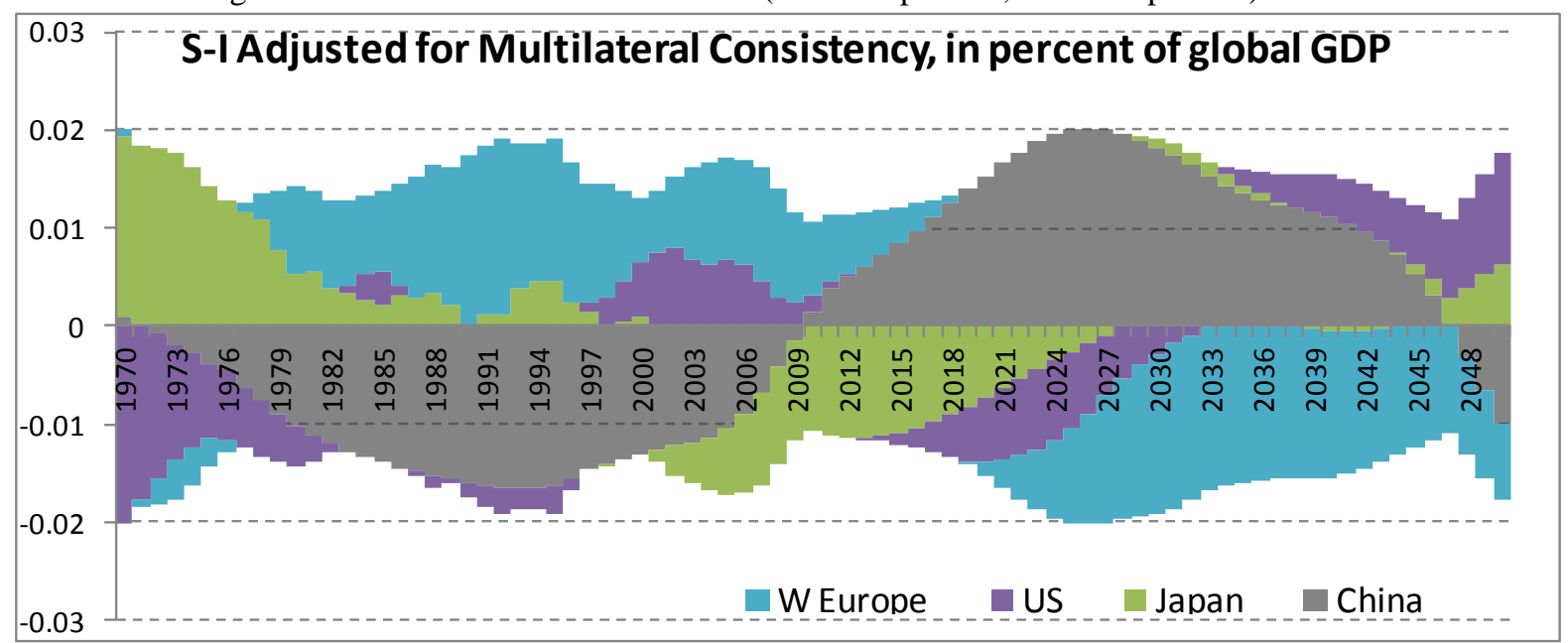

Alternative Scenario I: China GDP growth reduced to 2 percent; others no change.

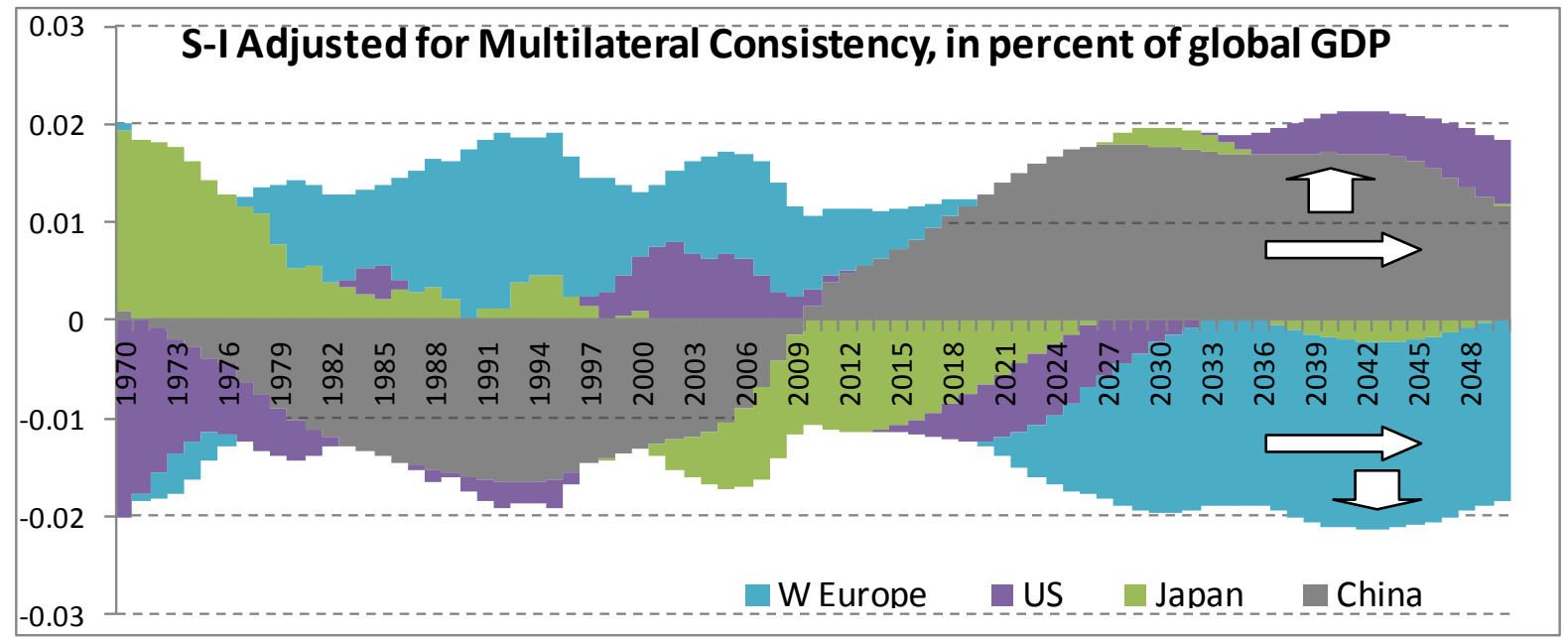

Alternative Scenario II: Weight of young reduced to 50 percent of working population and the old raised to 100 percent of the working population

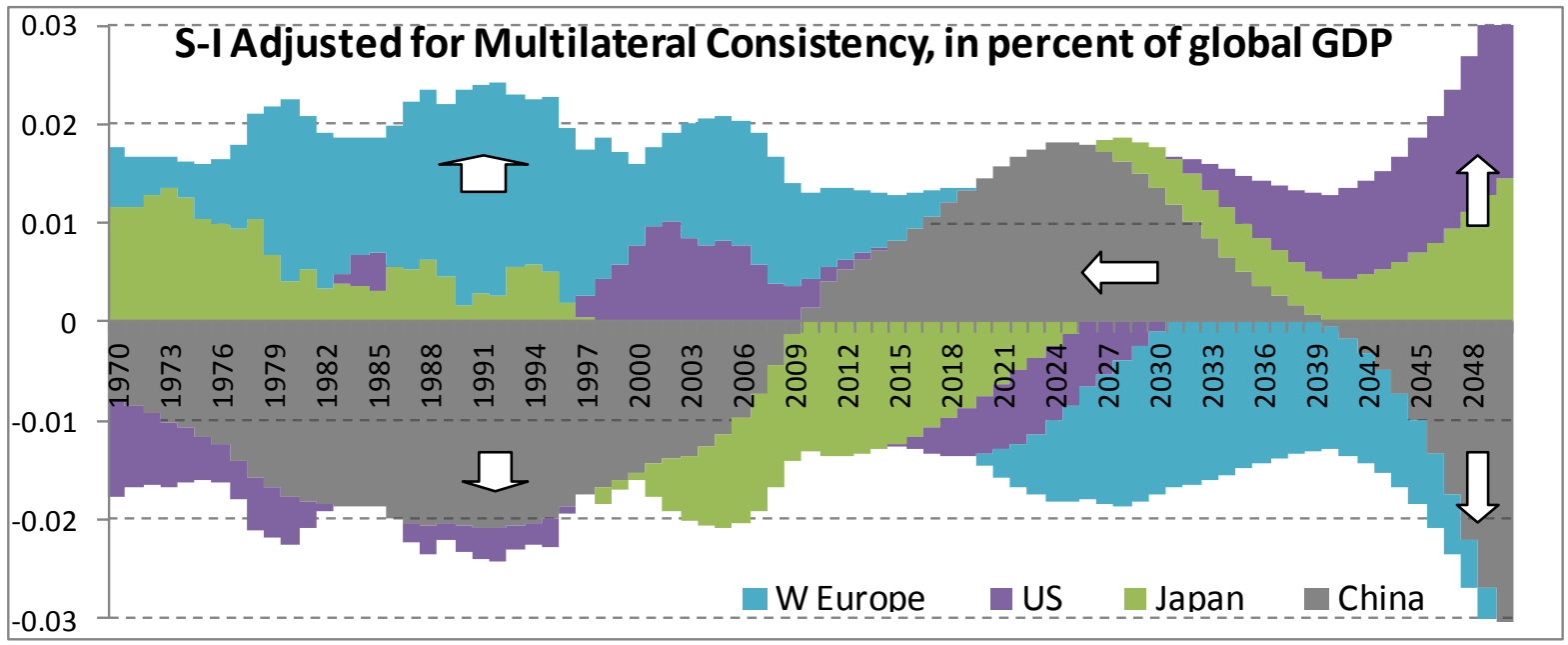

